\title{
Implementasi Statistical Process Control Untuk Minimasi Cacat Di PT. Bumimulia Indah Lestari
}

\author{
Hirawati Oemar ${ }^{1}$, Hery Hamdi Azwir ${ }^{2}$, Putra Fajar Pratama ${ }^{3}$ \\ 1) Fakultas Teknik, Departemen Teknik Industri, Universitas Islam Bandung \\ Jl. Tamansari No 20, Bandung 40116 \\ 2) Fakultas Teknik, Departemen Teknik Industri, President University \\ Jl. Ki Hajar Dewantara, Jababeka, Cikarang, Bekasi 17550 \\ 3) PT. Bumimulia Indah Lestari, Bekasi, Indonesia
}

E-mail: ${ }^{1}$ hirawatio@yahoo.co.id, ${ }^{2}$ hery.azwir@president.ac.id, ${ }^{3)}$ pratamafajarputra98@gmail.com

\begin{abstract}
ABSTRAK
Kualitas adalah salah satu indikator keberhasilan suatu perusahaan dalam memenuhi kepuasan pelanggan serta dapat meningkatkan daya saing dalam dunia industri. Kualitas sendiri memerlukan pengendalian dalam rangka mempertahankan dan meningkatkan standar semaksimal mungkin. Di PT Bumimulia Indah Lestari belum terdapat pengendalian proses dan kualitas secara optimal, terutama pada proses labelling sehingga proporsi produk cacat pada proses tersebut masih tinggi yang ditandai dengan defect label pada produk botol MF Cussons $900 \mathrm{ml}$. Salah satu usaha yang dapat mengurangi proporsi produk cacat yaitu dengan implementasi metode SPC (Statistical Processing Control). Alat bantu dari metode tersebut yang digunakan adalah bagan kendali $p$ ( $p$-chart) untuk mengukur proporsi produk cacat, diagram sebab-akibat (fishbone diagram) untuk mengetahui penyebab awal dari suatu permasalahan yang kemudian ditelusur lebih lanjut terkait akar dari masalahnya dengan Why Analysis, dan dari hasil serangkaian penelitian tersebut ditentukan action plan yang bertujuan meminimalisasi produk cacat dari berbagai aspek. Dengan implementasi SPC (Statistical Processing Control) pada proses labelling botol MF Cussons 900 $\mathrm{ml}$ maka proporsi produk cacat sudah terkendali, serta menurunkan presentase jumlah produk cacat dari 15,838\% menjadi 3,244\%.
\end{abstract}

Kata kunci: statistical processing control, defect, p-chart, why-why Analysis, quality improvement

\section{ABSTRACT}

Quality is one indicator of a company's success in meeting customer satisfaction and increasing competitiveness in the industrialized world. The quality itself requires control in order to maintain and improve the standards as much as possible. At PT Bumimulia Indah Lestari there is no optimal process and quality control, especially in the labeling process so that the proportion of defective products in the process is still high, which is indicated by a defect label on the $900 \mathrm{ml}$ MF Cussons bottle product. One effort that can reduce the proportion of defective products is the implementation of the SPC (Statistical Processing Control) method. The tools of the method used are p-chart to measure the proportion of defective products, cause-and-effect diagrams (fishbone diagrams) to find out the initial cause of a problem which is then explored further related to the root of the problem with Why Analysis, and from the results of a series of studies an action plan is determined which aims to minimize defective products from various aspects. With the implementation of SPC (Statistical Processing Control) on the labeling process of MF Cussons 900 $\mathrm{ml}$ bottles, the proportion of defective products has been controlled, and reduced the percentage of defective products from $15.838 \%$ to $3.244 \%$.

Keywords: statistical processing control, defect, p-chart, why-why analysis, quality improvement.

\section{Pendahuluan}

PT. Bumimulia Indah Lestarl adalah perusahaan yang berlokasi di kawasan industri Cikarang, Jawa Barat. Perusahaan ini bergerak di bidang manufaktur plastik seperti pembuatan kemasan plastik berupa botol, tube, jerrycan, dan pallet (Lestari, 2021). Suyadi (2007) mengatakan bahwa kualitas merupakan keadaan fisik dan fungsi serta sifat suatu produk tersebut, yang dapat memenuhi kebutuhan pelanggan dan sesuai dengan nilai yang dikeluarkan. Secara umum kualitas adalah evaluasi suatu produk yang tidak memiliki penyimpangan produksi dan memenuhi spesifikasi yang diinginkan oleh pelanggan (customer). Perusahaan saat ini memiliki 
masalah dengan kualitas produk yang ditunjukkan dengan indikator tingkat produk cacat yang tinggi. Salah satu masalah kualitas produk yang mempunyai tingkat cacat yang tinggi adalah produk botol MF Cussons dengan varian $900 \mathrm{ml}$ yang terjadi saat proses labelling. Proses ini merupakan proses pelabelan pada produk botol yang harus sesuai dengan spesifikasi dekorasi yang telah ditetapkan. Dampak yang ditimbulkan oleh tingkat cacat produk yang tinggi ini adalah perusahaan harus menambah biaya produksi dan biaya tenaga kerja untuk melakukan proses pengerjaan ulang (rework) dari botol hasil cacat labelling tersebut. Untuk memecahkan masalah diputuskan menggunakan SPC (Statistical Process Control) sebagai metode yang dapat membantu memperbaiki proses produksi. Gambar 1 adalah gambaran umum proses labelling yang dilakukan oleh perusahaan.

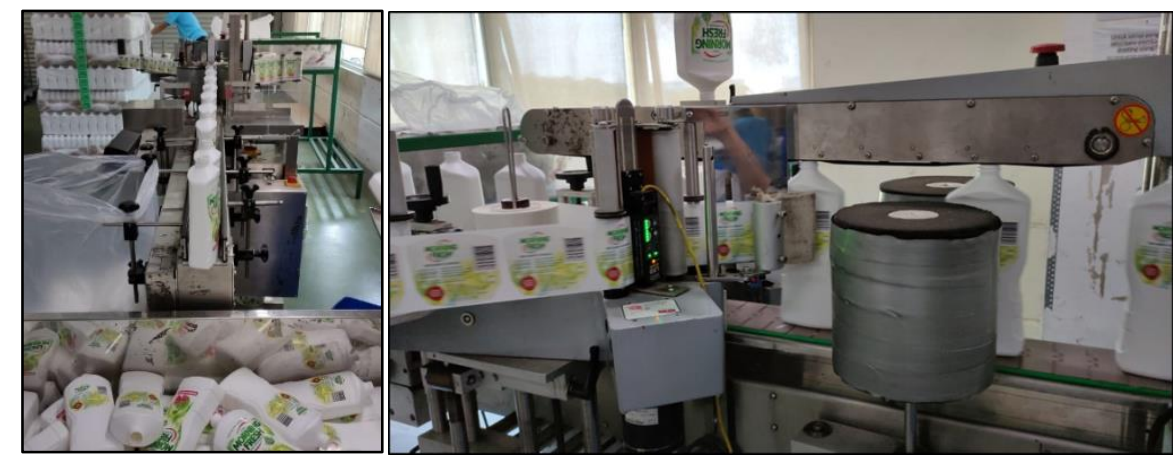

Gambar 1. Proses Labelling MF Cussons $900 \mathrm{ml}$

Menurut Heizer dan Render (2006), SPC merupakan suatu cara penyelesaian yang bertujuan mengawasi standar mutu, serta mengukur untuk memperoleh referensi dan opsi untuk tindakan yang nantinya akan dilakukan untuk mengatasi masalah yang ditemukan. Dalam implementasi di lapangan tidak harus seluruh alat bantu diggunakan, tergantung dari jenis masalah yang dihadapi dan batasan yang dimiliki oleh perusahaan dan kebutuhan masing-masing. SPC ini dipilih karena kesesuaian antara tujuan perusahaan dan keuntungan dalam penggunaan SPC yaitu dapat memonitoring, mengontrol dan meningkatkan efisiensi produksi dari segi kualitas produk yang dihasilkan. Pengendalian kualitas yang dilakukan yaitu melalui pembuatan bagan kendali (control chart) berdasarkan atribut dengan menggunakan p-chart, artinya pengukuran statistik dilakukan berdasarkan karakteristik produk cacat atau baik.

Melalui implementasi metode SPC ini perusahaan bisa mengetahui kondisi awal proses, menelusuri akar masalah, melakukan perbaikan, juga dapat untuk menganalisis lebih awal potensi penyimpangan yang terjadi pada produk, sehingga menjadi dasar keputusan tindakan pencegahan yang pada akhirnya dapat mengurangi jumlah produk cacat sekaligus meningkatkan profit perusahaan. Beberapa penelitian sebelumnya terkait penerapan SPC (Statistical Process Control) dalam rangka mengendalikan dan memonitor kualitas adalah oleh Kaban (2014) dengan judulnya yaitu "Pengendalian Kualitas Kemasan Plastik Pouch menggunakan Statistical Process Control (SPC) yang dilakukan di PT. Incasi Raya Padang”, juga penelitian yang dilakukan oleh Mirzaei dan Zare (2014) dengan judul penelitiannya adalah "Aplication of Statistical Process Control in service industry, a case study of the restaurant sector".

\section{Metode}

Penelitian diawali dengan observasi awal untuk mengamati proses secara kesuluruhan kemudian dilanjutkan dengan identifikasi masalah yang menjadi perhatian untuk dilakukan penelitian. Selanjutnya dilakukan pengumpulan data yag berhubungan dengan masalah tersebut, kemudian melakukan analisis melalui pembuatan control-chart, penelusuran akar masalah, perbaikan, melakukan uji hipotesis untuk menunjukkan memang benar terjadi perbaikan, dan hasil akhir untuk dibandingkan dengan kondisi sebelumnya.

Pengumpuan data produk cacat dilakukan dengan melihat data histori jumlah produk cacat dari bulan Januari sampai dengan Februari 2021, yaitu data sebelum diterapkannya perbaikan. Selanjutnya dilakukan pembuatan bagan kendali pertama, berdasarkan data cacat yang sudah dikumpulkan, diolah dan dihitung menjadi tabel sebagai alat bantu untuk proses pembuatan ini. Setelah Bagan kendali diketahui, jika ada beberapa data yang berada di luar batas kendali, maka data tersebut harus di buang ababila hasil investigasi menunjukkan faktor penyumbang produk cacat tersebut merupakan assignable cause, yang artinya penyebabnya diketahui yang biasanya berasal dari material, manusia, metode, dan bisa diatasi dengan beberapa tindakan perbaikan. Jadi bukan akibat noise biasa.

Setelah pengolahan data awal maka dilanjutkan dengan identifikasi masalah yang terjadi. Data yang di buang dalam proses sebelumnya, ditelusuri akar masalahnya, diselidiki jenis cacat yang ditimbulkan, guna 
mengetahui tindakan apa yang tepat dan dapat dilakukan perusahaan untuk mengurangi jumlah produk cacat yang dihasilkan. Dalam proses penelusuran ini setelah diketahui jenis cacat apa yang menjadi penyebabnya, kemudian dilakukan brainstorming dan analisis RCA (Root Cause Analysis). Dalam hal ini Why-Why Analysis terkait cacat tersebut, dan implementasi perbaikan/ solusi di lapangan dari hasil yang didapatkan.

Setelah perbaikan dilakukan maka dilakukan pengumpulan data produk cacat kembali dalam kurun waktu pertengahan Maret sampai dengan April 2021 yaitu dua minggu setelah pengambilan data pertama. Waktu dua minggu ini adalah waktu yang dibutuhkan untuk melakukan perbaikan. Data produk cacat tersebut, diolah dan dibuat kembali bagan kendali kedua setelah perbaikan. Selanjutnya dilakukan uji hipotesis yang bertujuan melihat perbedaan antara bagan kendali pertama dan kedua. Bagan kendali pertama yaitu sebelum perbaikan dan bagan kendali yang kedua yaitu setelah perbaikan diterapkan. Tujuan dari uji hipotesis ini adalah untuk menentukan apakah began kendali (control chart) kedua ini memang menunjukkan bukti bahwa rata-rata proses setelah perbaikan lebih baik atau tidak.

Dalam pembuatan p-chart, digunakan metode tiga (3) garis horizontal yang menunjukkan batas-batas yang dibuat secara visual untuk mengendalikan kualitas (Montgomery, 2013). Batas-batas tersebut dihitung dengan persamaan berikut:

> Centre line $(\mathrm{CL}) \square$ Garis horisontal yang berada di tengah di antara garis $\mathrm{UCL}$ dan $\mathrm{LCL}$, garis ini menunjukkan nilai tengah (mean) atau nilai rata-rata dari data yang terakumulasi, dengan perhitungan pada Persamaan (1) sebagai berikut:

$$
C L=\bar{p}=\frac{\sum(d)}{\Sigma(n)}
$$

> Upper Control Limit (UCL) $\square$ Garis horisontal yang berada di atas garis $\mathrm{CL}$ yang menunjukkan batas kendali atas dengan Persamaan (2) sebagai berikut:

$$
U C L=\bar{p}+3 \sqrt{\frac{\bar{p}(1-\bar{p})}{n_{i}}}
$$

> Lower Control Limit (LCL) $\square$ Garis horisontal yang berada di bawah garis $\mathrm{CL}$ yang menunjukkan batas kendali bawah dengan perhitungan seperti pada Persamaan (3) sebagai berikut:

$$
U C L=\bar{p}-3 \sqrt{\frac{\bar{p}(1-\bar{p})}{n_{i}}}
$$

Garis-garis tersebut ditentukan berdasarkan data historis, yaitu data produk cacat yang diambil dengan periode yang sudah ditentukan. Dari data di atas, pertama kita akan menghitung akumulasi dari produk cacat $\Sigma(\mathrm{d})$ dan sample $\Sigma(\mathrm{n})$. Jika jumlah sampel yang didapatkan tidak bisa konsisten dalam jumlah tertentu maka batas atas dab bawah $p$-chart yang hasilkan tidak bisa berupa garis lurus dan solusinya adalah melakukan aproksimasi dengan mencari sampel rata-rata dengan menggunakan Persamaan (4) dan (5).

$$
\begin{gathered}
\bar{n}=\frac{\left.\sum \text { (Sample size }\right)}{\sum(\text { Sample number })} \\
U C L / L C L=\bar{p} \pm 3 \sqrt{\frac{\bar{p}(1-\bar{p})}{\bar{n}}}
\end{gathered}
$$

\section{Hasil dan Pembahasan \\ 3.1. Pengumpulan Data}

Tahap ini dimulai dengan pengumpulan data produk cacat di bulan Januari sampai dengan Februari tahun 2021, di mana data yang dikumpulkan adalah data dengan presentase tertinggi yaitu pada proses labelling botol MF Cussons $900 \mathrm{ml}$. Produksi dari tiap produk tidak dilakukan setiap hari, tergantung dari rencana produksi yang disiapkan oleh PPIC di PT Bumimulia Indah Lestari. Pengamatan produk cacat dilakukan secara visual, dengan dua kategori yaitu baik atau cacat. Jika hasil pengamatannya cacat, maka dilakukanlah pengerjaan ulang dengan mengelupas dan membuang label yang cacat tersebut. Sedangkan proses penentuannya yaitu dengan mengacu kepada sample cacat yang tersedia di lapangan sebagaiman ditunjukkan dalam Gambar 2. Tabel 1 memperlihatkan data yang sudah dikumpulkan dan direkap. 

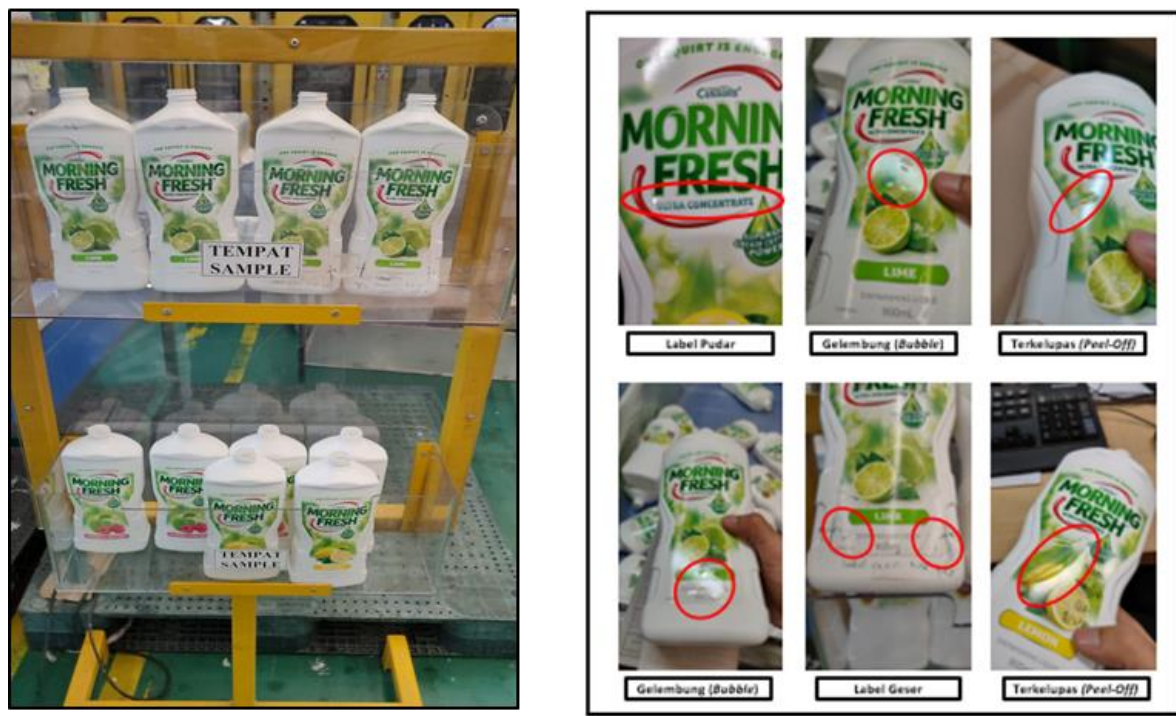

Gambar 2. Produk cacat

Tabel 1. Pengumpulan data periode Januari-Februari 2021

\begin{tabular}{|c|c|c|c|c|c|c|c|c|c|}
\hline No & Date & $\begin{array}{c}\text { Sum of Defect } \\
\text { Found (d) }\end{array}$ & $\begin{array}{c}\text { Sum of } \\
\text { Sample Size } \\
(\mathbf{n})\end{array}$ & $\mathbf{d} / \mathbf{n}$ & No & Date & $\begin{array}{c}\text { Sum of Defect } \\
\text { Found (d) }\end{array}$ & $\begin{array}{c}\text { Sum of } \\
\text { Sample Size } \\
(\mathbf{n})\end{array}$ & $\mathbf{d} / \mathbf{n}$ \\
\hline 1 & $04 / 01 / 2021$ & 20 & 145 & 0,138 & 21 & $25 / 01 / 2021$ & 27 & 148 & 0,182 \\
\hline 2 & $05 / 01 / 2021$ & 27 & 175 & 0,154 & 22 & $26 / 01 / 2021$ & 36 & 175 & 0,206 \\
\hline 3 & $06 / 01 / 2021$ & 14 & 125 & 0,112 & 23 & $27 / 01 / 2021$ & 43 & 254 & 0,169 \\
\hline 4 & $07 / 01 / 2021$ & 36 & 163 & 0,221 & 24 & $28 / 01 / 2021$ & 46 & 386 & 0,119 \\
\hline 5 & $08 / 01 / 2021$ & 41 & 232 & 0,177 & 25 & $29 / 01 / 2021$ & 21 & 200 & 0,105 \\
\hline 6 & $09 / 01 / 2021$ & 56 & 385 & 0,145 & 26 & $30 / 01 / 2021$ & 31 & 328 & 0,095 \\
\hline 7 & $10 / 01 / 2021$ & 48 & 350 & 0,137 & 27 & $31 / 01 / 2021$ & 52 & 340 & 0,153 \\
\hline 8 & $11 / 01 / 2021$ & 32 & 190 & 0,168 & 28 & $01 / 02 / 2021$ & 41 & 320 & 0,128 \\
\hline 9 & $13 / 01 / 2021$ & 27 & 214 & 0,126 & 29 & $02 / 02 / 2021$ & 24 & 215 & 0,112 \\
\hline 10 & $14 / 01 / 2021$ & 21 & 197 & 0,107 & 30 & $03 / 02 / 2021$ & 49 & 376 & 0,130 \\
\hline 11 & $15 / 01 / 2021$ & 21 & 180 & 0,117 & 31 & $04 / 02 / 2021$ & 45 & 416 & 0,108 \\
\hline 12 & $16 / 01 / 2021$ & 20 & 200 & 0,100 & 32 & $05 / 02 / 2021$ & 45 & 428 & 0,105 \\
\hline 13 & $17 / 01 / 2021$ & 21 & 200 & 0,105 & 33 & $06 / 02 / 2021$ & 30 & 320 & 0,094 \\
\hline 14 & $18 / 01 / 2021$ & 23 & 240 & 0,096 & 34 & $07 / 02 / 2021$ & 36 & 275 & 0,131 \\
\hline 15 & $19 / 01 / 2021$ & 42 & 348 & 0,121 & 35 & $08 / 02 / 2021$ & 25 & 274 & 0,091 \\
\hline 16 & $20 / 01 / 2021$ & 18 & 160 & 0,113 & 36 & $09 / 02 / 2021$ & 25 & 314 & 0,080 \\
\hline 17 & $21 / 01 / 2021$ & 34 & 354 & 0,096 & 37 & $10 / 02 / 2021$ & 29 & 298 & 0,097 \\
\hline 18 & $22 / 01 / 2021$ & 44 & 362 & 0,122 & 38 & $11 / 02 / 2021$ & 23 & 210 & 0,110 \\
\hline 19 & $23 / 01 / 2021$ & 14 & 148 & 0,095 & 39 & $12 / 02 / 2021$ & 51 & 400 & 0,128 \\
\hline 20 & $24 / 01 / 2021$ & 45 & 215 & 0,209 & 40 & $13 / 02 / 2021$ & 25 & 240 & 0,104 \\
\hline & & & & 41 & $14 / 02 / 2021$ & 23 & 210 & 0,110 \\
\hline & & & & & & 1331 & 10710 & 0.124 \\
\hline
\end{tabular}

\subsection{Pengolahan Data}

Setelah mendapatkan data produk cacat dilanjutkan dengan membuat bagan kendali. Karena data yang didapatkan adalah data atribut dan yang menjadi perhatian adalah proporsi cacat maka digunakan p-chart. Namun karena jumlah sampelnya tidak stabil maka nanti akan dilakukan standardisasi. Selanjutnya penentuan batas kendali dilakukan sebagai berikut: $\Sigma(\mathrm{d})=1331, \Sigma(\mathrm{n})=10710$

$$
C L=\bar{p}=\frac{\sum(d)}{\sum(n)}=\frac{1331}{10710}=0,124
$$

Kemudian menghitung UCL dan LCL pada setiap data, sebagai contoh data pertama dengan nilai $\mathrm{n}=145$. Dengan menggunakan Persamaan (4) dan (5) didapatkan hasil sebagai berikut: 


$$
\begin{aligned}
& U C L=\bar{p}+3 \sqrt{\frac{\bar{p}(1-\bar{p})}{n_{i}}}=0,124+3 \sqrt{\frac{0,124(1-0,124)}{145}}=0,206 \\
& L C L=\bar{p}-3 \sqrt{\frac{\bar{p}(1-\bar{p})}{n_{i}}}=0,124-3 \sqrt{\frac{0,124(1-0,124)}{145}}=0,042
\end{aligned}
$$

Diperoleh hasil seperti pada tabel 2 berikut:

Tabel 2. Hasil Perhitungan ( $P$-Chart) Data Periode Januari-Februari 2021

\begin{tabular}{|c|c|c|c|c|c|c|c|c|c|c|c|}
\hline No & Date & $\mathrm{d} / \mathrm{n}$ & $\mathrm{UCL}$ & $\mathrm{LCL}$ & $\mathrm{CL}$ & $\mathrm{No}$ & Date & $\mathrm{d} / \mathrm{n}$ & $\mathrm{UCL}$ & $\mathrm{LCL}$ & $\mathrm{CL}$ \\
& & & & & & & & & & & \\
\hline 1 & $04 / 01 / 2021$ & 0,138 & 0,206 & 0,042 & 0,124 & 21 & $25 / 01 / 2021$ & 0,182 & 0,206 & 0,043 & 0,124 \\
\hline 2 & $05 / 01 / 2021$ & 0,154 & 0,199 & 0,049 & 0,124 & 22 & $26 / 01 / 2021$ & 0,206 & 0,199 & 0,049 & 0,124 \\
\hline 3 & $06 / 01 / 2021$ & 0,112 & 0,213 & 0,036 & 0,124 & 23 & $27 / 01 / 2021$ & 0,169 & 0,186 & 0,062 & 0,124 \\
\hline 4 & $07 / 01 / 2021$ & 0,221 & 0,202 & 0,047 & 0,124 & 24 & $28 / 01 / 2021$ & 0,119 & 0,175 & 0,074 & 0,124 \\
\hline 5 & $08 / 01 / 2021$ & 0,177 & 0,189 & 0,059 & 0,124 & 25 & $29 / 01 / 2021$ & 0,105 & 0,194 & 0,054 & 0,124 \\
\hline 6 & $09 / 01 / 2021$ & 0,145 & 0,175 & 0,074 & 0,124 & 26 & $30 / 01 / 2021$ & 0,095 & 0,179 & 0,070 & 0,124 \\
\hline 7 & $10 / 01 / 2021$ & 0,137 & 0,177 & 0,071 & 0,124 & 27 & $31 / 01 / 2021$ & 0,153 & 0,178 & 0,071 & 0,124 \\
\hline 8 & $11 / 01 / 2021$ & 0,168 & 0,196 & 0,052 & 0,124 & 28 & $01 / 02 / 2021$ & 0,128 & 0,180 & 0,069 & 0,124 \\
\hline 9 & $13 / 01 / 2021$ & 0,126 & 0,192 & 0,057 & 0,124 & 29 & $02 / 02 / 2021$ & 0,112 & 0,192 & 0,057 & 0,124 \\
\hline 10 & $14 / 01 / 2021$ & 0,107 & 0,195 & 0,054 & 0,124 & 30 & $03 / 02 / 2021$ & 0,130 & 0,175 & 0,073 & 0,124 \\
\hline 11 & $15 / 01 / 2021$ & 0,117 & 0,198 & 0,051 & 0,124 & 31 & $04 / 02 / 2021$ & 0,108 & 0,173 & 0,076 & 0,124 \\
\hline 12 & $16 / 01 / 2021$ & 0,100 & 0,194 & 0,054 & 0,124 & 32 & $05 / 02 / 2021$ & 0,105 & 0,172 & 0,076 & 0,124 \\
\hline 13 & $17 / 01 / 2021$ & 0,105 & 0,194 & 0,054 & 0,124 & 33 & $06 / 02 / 2021$ & 0,094 & 0,180 & 0,069 & 0,124 \\
\hline 14 & $18 / 01 / 2021$ & 0,096 & 0,188 & 0,060 & 0,124 & 34 & $07 / 02 / 2021$ & 0,131 & 0,184 & 0,065 & 0,124 \\
\hline 15 & $19 / 01 / 2021$ & 0,121 & 0,177 & 0,071 & 0,124 & 35 & $08 / 02 / 2021$ & 0,091 & 0,184 & 0,064 & 0,124 \\
\hline 16 & $20 / 01 / 2021$ & 0,113 & 0,203 & 0,046 & 0,124 & 36 & $09 / 02 / 2021$ & 0,080 & 0,180 & 0,068 & 0,124 \\
\hline 17 & $21 / 01 / 2021$ & 0,096 & 0,177 & 0,072 & 0,124 & 37 & $10 / 02 / 2021$ & 0,097 & 0,182 & 0,067 & 0,124 \\
\hline 18 & $22 / 01 / 2021$ & 0,122 & 0,176 & 0,072 & 0,124 & 38 & $11 / 02 / 2021$ & 0,110 & 0,193 & 0,056 & 0,124 \\
\hline 19 & $23 / 01 / 2021$ & 0,095 & 0,206 & 0,043 & 0,124 & 39 & $12 / 02 / 2021$ & 0,128 & 0,174 & 0,075 & 0,124 \\
\hline 20 & $24 / 01 / 2021$ & 0,209 & 0,192 & 0,057 & 0,124 & 40 & $13 / 02 / 2021$ & 0,104 & 0,188 & 0,060 & 0,124 \\
\hline & & & & & & 41 & $14 / 02 / 2021$ & 0,110 & 0,193 & 0,056 & 0,124 \\
\hline
\end{tabular}

Dari hasil perhitungan tabel di atas, terlihat bahwa ada beberapa data yang mempunyai proporsi cacat yang melebihi batas, dalam hal ini UCL. Karena itu perlu diselidiki apa yang terjadi di pengambilan sampel saat itu. Dari pemeriksaan diketahui bahwa sampel ke-4, ke-20, dan ke-22 telah diluar batas kendali akibat adanya assignable causes sehingga sampel ketiga waktu tersebut diputuskan untuk dibuang. Jadi hasil perhitungan setelah dikurangi dengan sampel yang dikeluarkan menjadi:

Sampel yang dikeluarkan : $\Sigma(\mathrm{d})$ dibuang $=117, \Sigma(\mathrm{n})$ dibuang $=553$, sehingga akhirnya $\Sigma(\mathrm{d})=1331-117=1214$ dan $\Sigma(\mathrm{n})=10710-553=10157$, kemudian $C L=\bar{p}=\frac{1214}{10157}=0,120$. Selanjutnya berdasarkan revisi tersebut dilakukan perhitungan kembali untuk mendapatkan $p$-chart revisi. Tabel 3 memperlihatkan $p$-chart revisi.

Tabel 3. Hasil Perhitungan (P-Chart) Data Periode Januari-Februari 2021

\begin{tabular}{|c|c|c|c|c|c|c|c|c|c|c|c|}
\hline No & Date & $\mathrm{d} / \mathbf{n}$ & $\mathrm{UCL}$ & $\mathrm{LCL}$ & $\mathrm{CL}$ & No & Date & $\mathrm{d} / \mathbf{n}$ & $\mathrm{UCL}$ & $\mathrm{LCL}$ & $\mathrm{CL}$ \\
\hline 1 & $04 / 01 / 2021$ & 0,138 & 0,200 & 0,039 & 0,120 & 21 & $28 / 01 / 2021$ & 0,119 & 0,169 & 0,070 & 0,120 \\
\hline 2 & $05 / 01 / 2021$ & 0,154 & 0,193 & 0,046 & 0,120 & 22 & $29 / 01 / 2021$ & 0,105 & 0,188 & 0,051 & 0,120 \\
\hline 3 & $06 / 01 / 2021$ & 0,112 & 0,207 & 0,032 & 0,120 & 23 & $30 / 01 / 2021$ & 0,095 & 0,173 & 0,066 & 0,120 \\
\hline 4 & $08 / 01 / 2021$ & 0,177 & 0,183 & 0,056 & 0,120 & 24 & $31 / 01 / 2021$ & 0,153 & 0,172 & 0,067 & 0,120 \\
\hline 5 & $09 / 01 / 2021$ & 0,145 & 0,169 & 0,070 & 0,120 & 25 & $01 / 02 / 2021$ & 0,128 & 0,174 & 0,065 & 0,120 \\
\hline 6 & $10 / 01 / 2021$ & 0,137 & 0,172 & 0,068 & 0,120 & 26 & $02 / 02 / 2021$ & 0,112 & 0,186 & 0,053 & 0,120 \\
\hline 7 & $11 / 01 / 2021$ & 0,168 & 0,190 & 0,049 & 0,120 & 27 & $03 / 02 / 2021$ & 0,130 & 0,170 & 0,069 & 0,120 \\
\hline 8 & $13 / 01 / 2021$ & 0,126 & 0,186 & 0,053 & 0,120 & 28 & $04 / 02 / 2021$ & 0,108 & 0,167 & 0,072 & 0,120 \\
\hline 9 & $14 / 01 / 2021$ & 0,107 & 0,189 & 0,050 & 0,120 & 29 & $05 / 02 / 2021$ & 0,105 & 0,167 & 0,072 & 0,120 \\
\hline 10 & $15 / 01 / 2021$ & 0,117 & 0,192 & 0,047 & 0,120 & 30 & $06 / 02 / 2021$ & 0,094 & 0,174 & 0,065 & 0,120 \\
\hline
\end{tabular}




\begin{tabular}{|c|c|c|c|c|c|c|c|c|c|c|c|}
\hline No & Date & $\mathrm{d} / \mathbf{n}$ & $\mathrm{UCL}$ & $\mathrm{LCL}$ & $\mathrm{CL}$ & No & Date & $\mathrm{d} / \mathbf{n}$ & $\mathrm{UCL}$ & $\mathrm{LCL}$ & $\mathrm{CL}$ \\
\hline 11 & $16 / 01 / 2021$ & 0,100 & 0,188 & 0,051 & 0,120 & 31 & $07 / 02 / 2021$ & 0,131 & 0,178 & 0,061 & 0,120 \\
\hline 12 & $17 / 01 / 2021$ & 0,105 & 0,188 & 0,051 & 0,120 & 32 & $08 / 02 / 2021$ & 0,091 & 0,178 & 0,061 & 0,120 \\
\hline 13 & $18 / 01 / 2021$ & 0,096 & 0,182 & 0,057 & 0,120 & 33 & $09 / 02 / 2021$ & 0,080 & 0,174 & 0,065 & 0,120 \\
\hline 14 & $19 / 01 / 2021$ & 0,121 & 0,172 & 0,067 & 0,120 & 34 & $10 / 02 / 2021$ & 0,097 & 0,176 & 0,063 & 0,120 \\
\hline 15 & $20 / 01 / 2021$ & 0,113 & 0,196 & 0,043 & 0,120 & 35 & $11 / 02 / 2021$ & 0,110 & 0,187 & 0,052 & 0,120 \\
\hline 16 & $21 / 01 / 2021$ & 0,096 & 0,171 & 0,068 & 0,120 & 36 & $12 / 02 / 2021$ & 0,128 & 0,168 & 0,071 & 0,120 \\
\hline 17 & $22 / 01 / 2021$ & 0,122 & 0,171 & 0,068 & 0,120 & 37 & $13 / 02 / 2021$ & 0,104 & 0,182 & 0,057 & 0,120 \\
\hline 18 & $23 / 01 / 2021$ & 0,095 & 0,200 & 0,040 & 0,120 & 38 & $14 / 02 / 2021$ & 0,110 & 0,187 & 0,052 & 0,120 \\
\hline 19 & $25 / 01 / 2021$ & 0,182 & 0,200 & 0,040 & 0,120 & & & & & & \\
\hline 20 & $27 / 01 / 2021$ & 0,169 & 0,181 & 0,058 & 0,120 & & & & & & \\
\hline
\end{tabular}

Berdasarkan hasil perhitungan sebagaimana diperlihatkan dalam Tabel 3, semua data berada dalam batas kendali artinya tidak ada lagi data yang perlu dibuang dan grafik yang akan dihasilkan sudah dalam keadaan normal atau dalam batas kendali. Gambar 3 memperlihatkan grafik p-chart yang menunjukkan hasil perhitungan terbaru.

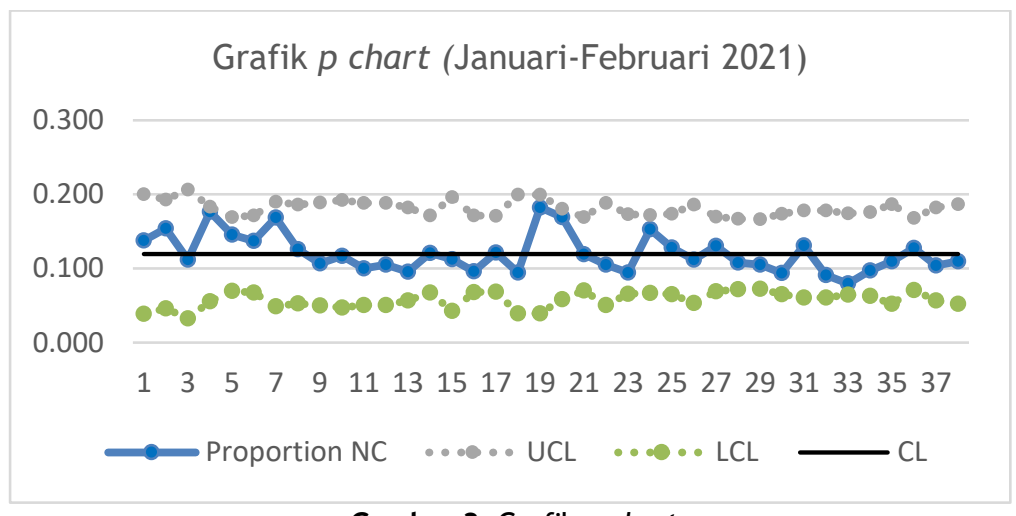

Gambar 3. Grafik p-chart

Kekurangan daro $p$-chart yang telah didapatkan adalah batas atas dan batas bawah bervariasi akibat ukuran sampel yang tidak konsisten sehingga hal ini akan menyulitkan dalam melakukan analisis. Untuk itu $p$-chart ini dapat direvisi kembali dengan membuat standardisasi melalui penentuan ukuran sampel secara rata-rata sehingga bisa didapatkan p-chart yang memiliki batas atas dan bawah yang tetap. Berikut hasil perhitungan dari bagan kendali yang telah dibuat menjadi standar:

$$
\begin{gathered}
C L=\bar{p}=\frac{1214}{10157}=0,120 \text { dan } \bar{n}=\frac{10157}{38}=267,29 \\
U C L=\bar{p}+3 \sqrt{\frac{\bar{p}(1-\bar{p})}{\bar{n}}}=0,12+3 \sqrt{\frac{0,12(1-0,12)}{267,29}}=0,18 \\
L C L=\bar{p}-3 \sqrt{\frac{\bar{p}(1-\bar{p})}{\bar{n}}}=0,12-3 \sqrt{\frac{0,12(1-0,12)}{267,29}}=0,06
\end{gathered}
$$

Dengan menggunakan bagan kendali yang baru maka akan didapatkan hasil sebagaimana yang diperlihatkan dalam Tabel4. Untuk lebih memudahkan visualisasi p-chart maka dapat dilihat dalam Gambar 4. 


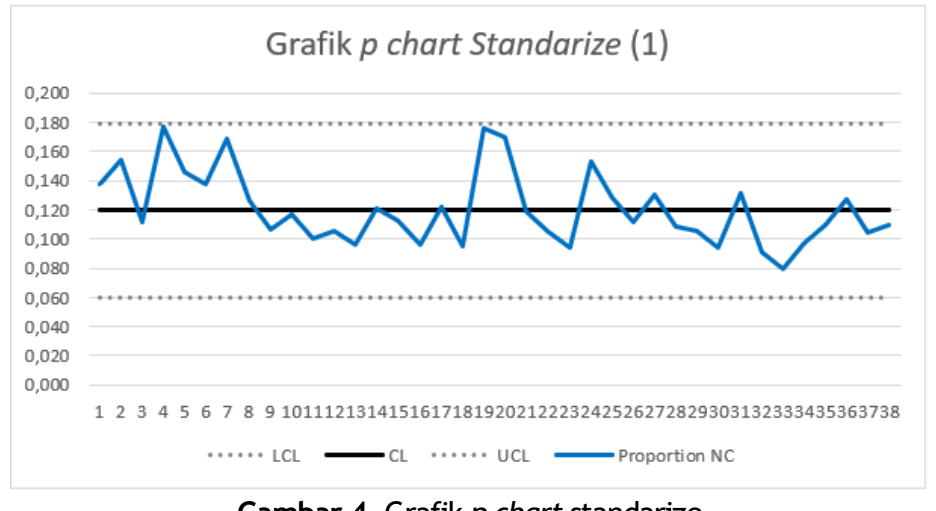

\subsection{Analisis dan Upaya Perbaikan}

Berdasarkan p-chart yang ditunjukkan dalam Gambar 4, dapat terlihat bahwa fluktuasi yang terjadi masih cukup tinggi. Hal ini menunjukkan perlunya dilakukan perbaikan proses. Maka tahap berikutnya adalah melakukan investigasi dan mencari akar masalah terkait jenis cacat produk. Dari hasil investigasi terkait jumlah dan jenis cacat ditemukan dua jenis cacat terbanyak yaitu bubble dan peel-off, sebagaimana diperlihatkan dalam Gambar 5, dan cukup signifikan muncul saat pengumpulan data awal yaitu:

- Pada tanggal 7 Januari 2021 (data ke-4) jenis cacat/ defect yang paling banyak ditemukan adalah gelembung (bubble).

- Pada tanggal 24 Januari 2021 (data ke-20) jenis cacat/ defect yang paling banyak ditemukan adalah gelembung (bubble).

- Pada tanggal 26 Januari 2021 (data ke-22) jenis cacat/ defect yang paling banyak ditemukan adalah terkelupas (peel-off).

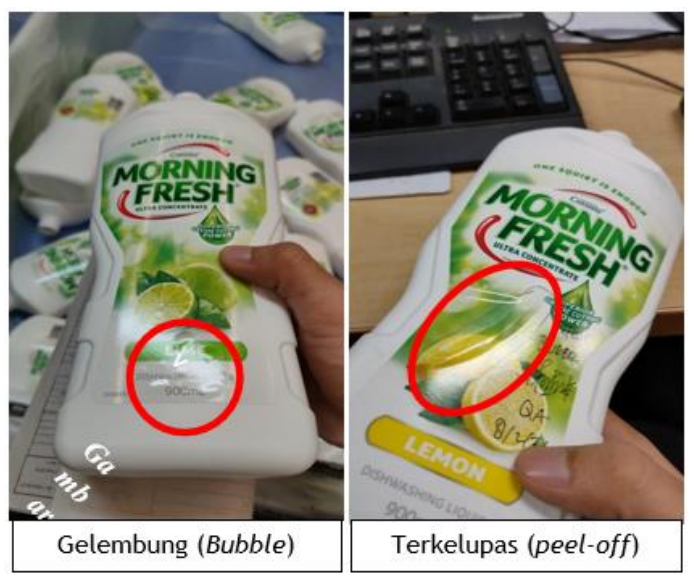

Gambar 5. Jenis cacat di proses labelling

Untuk menelusuri sumber penyebab terjadinya bubble dilakukan fishbone analysis (lihat Gambar 6). Berdasarkan hasil penelusuran ditemukan bahwa terdapat empat faktor yang berkontribusi pada munculnya gelembung (buble). Pertama yaitu faktor material, ditemukan bahwa lem yang terdapat pada label ternyata tidak merata dengan baik diseluruh permukaannya. Kedua ialah faktor metode, ternyata tidak ada standard operating procedure atau work instruction untuk inspeksi sehingga tidak ada panduan yang jelas bagaimana melakukan pemeriksaan dengan benar. Ketiga adalah faktor mesin, setting dari sweeper dan holder pelabelan murang sesuai. Keempat yakni faktor lingkungan (environment), label yang disimpan di gudang ternyata memiliki lingkungan yang kurang baik sehingga dapat mengakibatkan kerusakan label. 


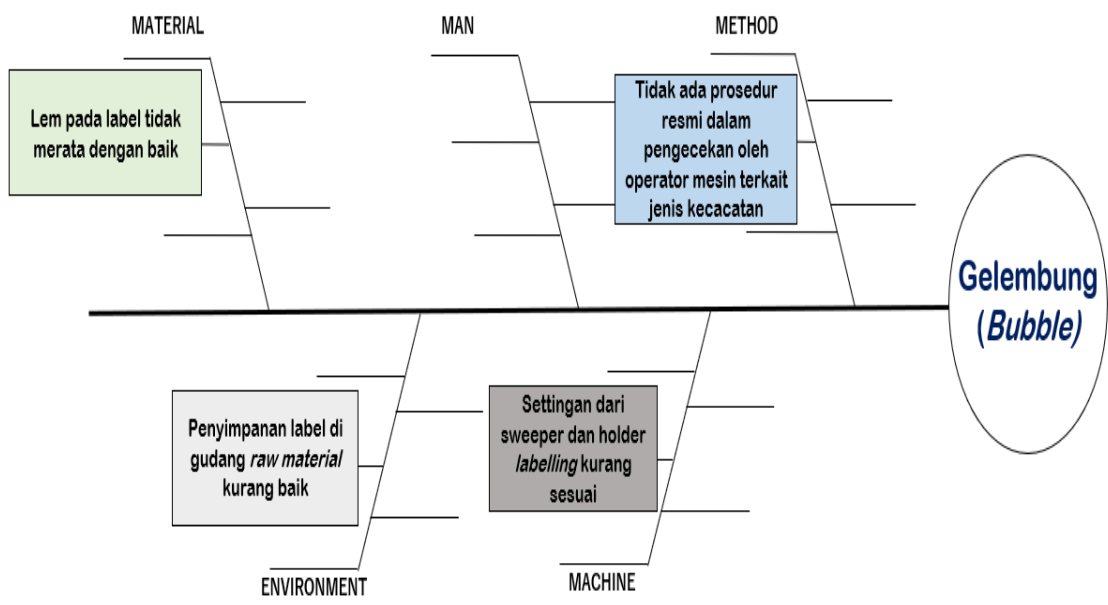

Gambar 6. Ishikawa diagram Gelembung (bubble)

Setelah masalah dari masing-masing faktor ditemukan maka selanjutnya adalah mencari solusi. Metode yang digunakan adalah menggunakan Why Analysis dan Action Plan sebagaimana dijelaskan dalam Tabel 5. Melalui analisis lebih mendalam ditemukan sumber masalah untuk material adalah akibat suhu penyimpanan label yang tidak stabil. Untuk Mesin sumber masalahnya adalah akibat setting tools-nya telah aus. Sumber masalah untuk metode adalah akibat kurangnya materi pelatihan terkait jenis kecacatan pada produk MF Cusson 900 $\mathrm{ml}$. Terakhir yang berkaitan dengan lingkungan adalah kapasitas penyimpanan di gudang yang tidak mencukupi sehingga diletakkan tidak pada tempatnya.

Tindakan yang dilakukan atau corrective action nya adalah memasang pengatur suhu ruangan (AC) untuk faktor material. Mengganti alat bantu setting tools dengan yang baru. Melakukan revisi materi pelatihan yaitu melengkapinya dengan informasi cacat produk MF Cusson 900. Sedangkan untuk penyimpanan label dicarikan lokasi penyimpanan yang lebih baik kondisi lingkungannya.

Tabel 5. Why Analysis, Action plan \& Permanent Action Gelembung (bubble)

\begin{tabular}{|c|c|c|c|c|c|c|c|c|}
\hline & Material & Machine & Method & Environment & No & Root Cause & Action Plan & Due Date \\
\hline \multirow{2}{*}{ Why 1} & \multirow{2}{*}{$\begin{array}{c}\begin{array}{c}\text { Lem pada } \\
\text { label tidak } \\
\text { merata dengan } \\
\text { baik }\end{array} \\
\end{array}$} & \multirow{2}{*}{$\begin{array}{l}\text { Setelan dari } \\
\text { sweeper pada } \\
\text { mesin Labelling } \\
\text { kurang sesuai }\end{array}$} & \multirow{2}{*}{$\begin{array}{c}\text { Tidak ada } \\
\text { perintah dalam } \\
\text { pengecekan } \\
\text { oleh operator } \\
\text { mesin terkait } \\
\text { jenis kecacatan }\end{array}$} & \multirow{2}{*}{$\begin{array}{l}\text { Penyimpanan } \\
\text { label di gudang } \\
\text { raw material } \\
\text { kurang baik }\end{array}$} & 1 & $\begin{array}{c}\text { Suhu penyimpanan label tidak } \\
\text { stabil }\end{array}$ & $\begin{array}{l}\text { Pengadaan fasilitas untuk } \\
\text { mengontrol suhu dalam } \\
\text { ruangan berupa AC }\end{array}$ & Week 8 \\
\hline & & & & & 2 & Alat tersebut sudah aus & $\begin{array}{c}\text { Mengganti alat bantu } \\
\text { tersebut dengan yang baru }\end{array}$ & Week 7 \\
\hline \multirow{3}{*}{ Why 2} & \multirow{3}{*}{$\begin{array}{c}\text { Suhu } \\
\text { penyimpanan } \\
\text { label tidak } \\
\text { stabil }\end{array}$} & \multirow{3}{*}{$\begin{array}{l}\text { Operasional } \\
\text { dari sweeper } \\
\text { tidak } \\
\text { maksimal }\end{array}$} & \multirow{3}{*}{$\begin{array}{c}\text { Materi training } \\
\text { awal belum } \\
\text { terdapat jenis } \\
\text { kecacatan pada } \\
\text { produk MF } \\
\text { Cussons } 900 \mathrm{ml}\end{array}$} & \multirow{3}{*}{$\begin{array}{l}\text { Dalam suatu } \\
\text { waktu, } \\
\text { kapasitas } \\
\text { penyimpanan } \\
\text { berlebih }\end{array}$} & 3 & $\begin{array}{l}\text { Materi training awal belum } \\
\text { terdapat jenis kecacatan pada } \\
\text { produk MF Cussons } 900 \mathrm{ml}\end{array}$ & $\begin{array}{c}\text { Penambahan materi } \\
\text { training terkait hal } \\
\text { tersebut }\end{array}$ & Week 7 \\
\hline & & & & & No & Root Cause & Action Plan & Due Date \\
\hline & & & & & 4 & $\begin{array}{l}\text { Dalam suatu waktu, kapasitas } \\
\text { penyimpanan berlebih }\end{array}$ & $\begin{array}{l}\text { Menyediakan alternatif } \\
\text { penyimpanan raw material }\end{array}$ & Week 8 \\
\hline Why 3 & - & $\begin{array}{l}\text { Alat tersebut } \\
\text { sudah aus }\end{array}$ & - & - & \multicolumn{4}{|c|}{$\begin{array}{l}\text { PERMANENT ACTION (State in the blank below) } \\
\text { 1. Pengadaan sample cacat di line produksi tentang jenis kecacatan pada } \\
\text { produk MF Cussons } 900 \mathrm{ml} \\
\text { 2. Menyediakan tempatat alternatif untuk penyimpanan label dalam ruang } \\
\text { tertutup dan difasilitasi dengan AC }\end{array}$} \\
\hline
\end{tabular}

Selanjutnya adalah penelusuran penyebab terjadinya cacat akibat terkelupas (peel-off). Di sini ditemukan tiga faktor yang berkontribusi pada kecacatan tersebut. Pertama adalah faktor Material yaitu, keadaan fisik dari label menyusut atau mengkerut. Kedua adalah faktor mesin, setting dari holder pada mesin labelling kurang sesuai. Ketiga adalah faktor metode di mana proses pemuaian botol masih terjadi saat pelabelan dilakukan. 


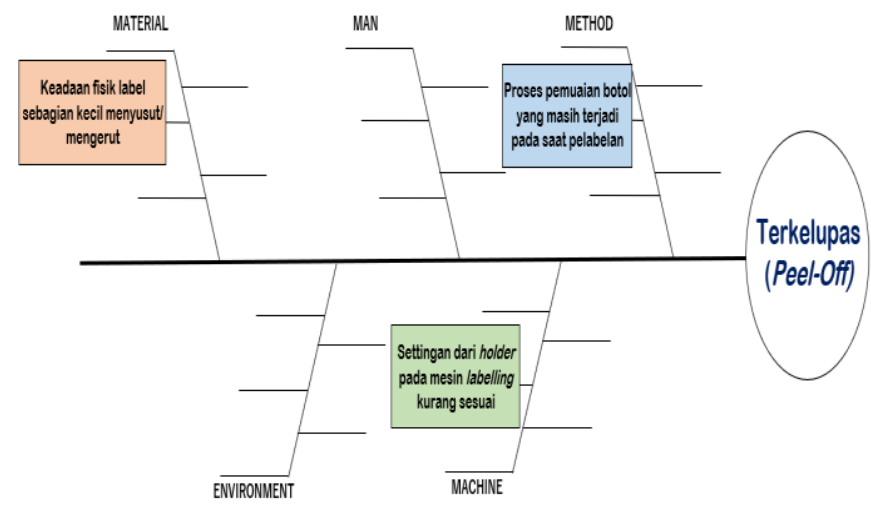

Gambar 7. Ishikawa diagram Terkelupas (Peel-off)

Kembali dengan menggunakan Why Analysis dan action plan penelusuran akar masalah hingga rencana perbaikan dilakukan. Pertama untuk faktor material ditemukan bahwa akar masalahnya adalah suhu penyimpanan label yang melewati batas yang diizinkan yaitu terlalu dingin atau terlalu panas. Kedua faktor mesin, ditemukan bahwa akar masalahnya adalah sama dengan cacat sebelumnya yaitu setelan manual yang tidak konsisten atau sering berubah-ubah. Ketiga yaitu faktor metode, akar masalahnya adalah alur produksi dalam pelabelan tanpa adanya waktu tunggu dan sangat dinamis, dan hal ini ujungnya disebabkan oleh tidak terdapatnya standard operating procedure atau work instruction yang jelas mengenai waktu tunggu dalam proses pelabelan.

Untuk corrective actionnya adalah melakukan fasilitas pengendali suhu ruangan (AC) yang terkait penyimpanan material. Melakukan penyetelan ulang holder dan pengecekan secara berkala yang dilakukan oleh operator, untuk faktor mesin. Sedangkan untuk faktor metode, dilakukan revisi terhadap prosedur yaitu adanya penambahan proses aging pada transisi awal proses pelabelan.

Tabel 6. Why Analysis, Action plan \& Permanent Action Terkelupas (Peel-off)

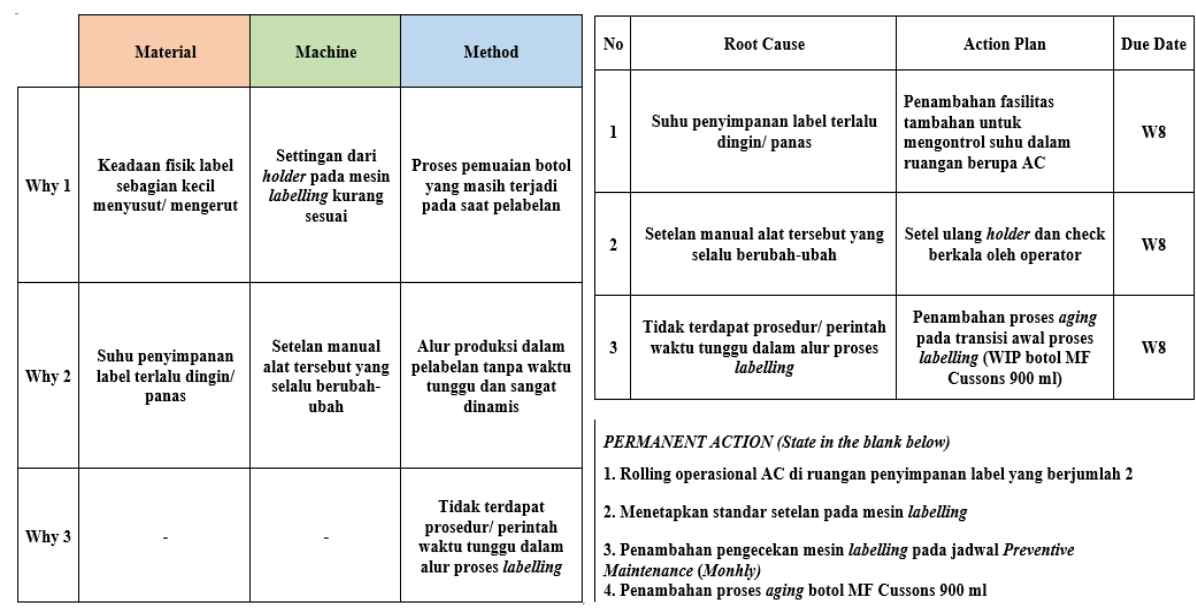

Pengimplementasian seluruh perbaikan pada proses labelling membutuhkan waktu kurang lebih 2 minggu, maka dari itu pengambilan data selanjutnya di periode bulan Maret sampai dengan bulan April 2021 dengan harapan tingkat produk cacat yang menurun dibandingkan dengan sebelumnya. Berikut pengambilan data ke2 yang dilakukan pada bulan Maret sampai dengan bulan April 2021, yaitu sebagai berikut:

Tabel 7. Pengumpulan Data Periode Maret-April 2021

\begin{tabular}{|c|c|c|c|c|c|c|c|c|c|}
\hline No & Date & $\begin{array}{l}\text { Sum of Defect } \\
\text { Found (d) }\end{array}$ & $\begin{array}{l}\text { Sum of } \\
\text { Sample Size } \\
\text { (n) }\end{array}$ & $d / n$ & No & Date & $\begin{array}{l}\text { Sum of Defect } \\
\text { Found (d) }\end{array}$ & $\begin{array}{l}\text { Sum of } \\
\text { Sample } \\
\text { Size (n) }\end{array}$ & $d / n$ \\
\hline 1 & $01 / 03 / 2021$ & 4 & 175 & 0,023 & 21 & $25 / 03 / 2021$ & 5 & 289 & 0,017 \\
\hline 2 & $02 / 03 / 2021$ & 6 & 318 & 0,019 & 22 & $26 / 03 / 2021$ & 7 & 254 & 0,028 \\
\hline 3 & $03 / 03 / 2021$ & 8 & 265 & 0,030 & 23 & $27 / 03 / 2021$ & 5 & 176 & 0,028 \\
\hline 4 & $04 / 03 / 2021$ & 3 & 184 & 0,016 & 24 & $28 / 03 / 2021$ & 7 & 327 & 0,021 \\
\hline 5 & $07 / 03 / 2021$ & 5 & 267 & 0,019 & 25 & $29 / 03 / 2021$ & 3 & 233 & 0,013 \\
\hline 6 & $08 / 03 / 2021$ & 9 & 363 & 0,025 & 26 & $30 / 03 / 2021$ & 7 & 298 & 0,023 \\
\hline
\end{tabular}




\begin{tabular}{|c|c|c|c|c|c|c|c|c|c|}
\hline No & Date & $\begin{array}{l}\text { Sum of Defect } \\
\text { Found (d) }\end{array}$ & $\begin{array}{c}\text { Sum of } \\
\text { Sample Size } \\
\text { (n) }\end{array}$ & $d / n$ & No & Date & $\begin{array}{l}\text { Sum of Defect } \\
\text { Found (d) }\end{array}$ & $\begin{array}{l}\text { Sum of } \\
\text { Sample } \\
\text { Size (n) }\end{array}$ & $d / n$ \\
\hline 7 & $09 / 03 / 2021$ & 9 & 417 & 0,022 & 27 & $31 / 03 / 2021$ & 11 & 485 & 0,023 \\
\hline 8 & $10 / 03 / 2021$ & 4 & 347 & 0,012 & 28 & $01 / 04 / 2021$ & 5 & 214 & 0,023 \\
\hline 9 & $11 / 03 / 2021$ & 8 & 314 & 0,025 & 29 & $02 / 04 / 2021$ & 8 & 317 & 0,025 \\
\hline 10 & $12 / 03 / 2021$ & 10 & 429 & 0,023 & 30 & $03 / 04 / 2021$ & 5 & 326 & 0,015 \\
\hline 11 & $13 / 03 / 2021$ & 8 & 364 & 0,022 & 31 & $04 / 04 / 2021$ & 8 & 268 & 0,030 \\
\hline 12 & $14 / 03 / 2021$ & 7 & 376 & 0,019 & 32 & $05 / 04 / 2021$ & 4 & 326 & 0,012 \\
\hline 13 & $15 / 03 / 2021$ & 12 & 459 & 0,026 & 33 & $06 / 04 / 2021$ & 8 & 321 & 0,025 \\
\hline 14 & $16 / 03 / 2021$ & 6 & 326 & 0,018 & 34 & $07 / 04 / 2021$ & 5 & 253 & 0,020 \\
\hline 15 & $17 / 03 / 2021$ & 6 & 259 & 0,023 & 35 & $08 / 04 / 2021$ & 3 & 260 & 0,012 \\
\hline 16 & $18 / 03 / 2021$ & 8 & 353 & 0,023 & 36 & $09 / 04 / 2021$ & 3 & 215 & 0,014 \\
\hline 17 & $19 / 03 / 2021$ & 5 & 253 & 0,020 & 37 & $10 / 04 / 2021$ & 7 & 307 & 0,023 \\
\hline 18 & $20 / 03 / 2021$ & 3 & 221 & 0,014 & 38 & $11 / 04 / 2021$ & 7 & 209 & 0,033 \\
\hline 19 & $21 / 03 / 2021$ & 9 & 352 & 0,026 & 39 & $12 / 04 / 2021$ & 5 & 375 & 0,013 \\
\hline 20 & $24 / 03 / 2021$ & 11 & 416 & 0,026 & 40 & $13 / 04 / 2021$ & 3 & 312 & 0,010 \\
\hline & & & & & 41 & $14 / 04 / 2021$ & 8 & 337 & 0,024 \\
\hline \multicolumn{7}{|c|}{ Jumlah / rata-rata } & 265 & 12560 & 0.021 \\
\hline
\end{tabular}

Setelah perbaikan, terlihat jelas perbedaan atau penurunan jumlah produk cacat di proses labelling. Kemudian dibuatkan tabel perhitungan UCL, LCL, dan CL dengan perhitungan dan rumus yang sama untuk data produk Januari-Februari lalu. Berikut hasil perhitungan menggunakan rumus tersebut untuk data dalam jangka waktu 2 bulan (Maret dan April 2021) yaitu sebagai berikut:

Tabel 8. Hasil Perhitungan (P-Chart) Data Periode Maret-April 2021

\begin{tabular}{|c|c|c|c|c|c|c|c|c|c|c|c|}
\hline No & Date & $\mathrm{d} / \mathrm{n}$ & $\mathrm{UCL}$ & $\mathrm{LCL}$ & $\mathrm{CL}$ & $\mathrm{No}$ & Date & $\mathrm{d} / \mathrm{n}$ & $\mathrm{UCL}$ & $\mathrm{LCL}$ & $\mathrm{CL}$ \\
\hline 1 & $01 / 03 / 2021$ & 0,023 & 0,054 & $-0,011$ & 0,021 & 21 & $25 / 03 / 2021$ & 0,017 & 0,046 & $-0,004$ & 0,021 \\
\hline 2 & $02 / 03 / 2021$ & 0,019 & 0,045 & $-0,003$ & 0,021 & 22 & $26 / 03 / 2021$ & 0,028 & 0,048 & $-0,006$ & 0,021 \\
\hline 3 & $03 / 03 / 2021$ & 0,030 & 0,048 & $-0,005$ & 0,021 & 23 & $27 / 03 / 2021$ & 0,028 & 0,054 & $-0,011$ & 0,021 \\
\hline 4 & $04 / 03 / 2021$ & 0,016 & 0,053 & $-0,011$ & 0,021 & 24 & $28 / 03 / 2021$ & 0,021 & 0,045 & $-0,003$ & 0,021 \\
\hline 5 & $07 / 03 / 2021$ & 0,019 & 0,047 & $-0,005$ & 0,021 & 25 & $29 / 03 / 2021$ & 0,013 & 0,049 & $-0,007$ & 0,021 \\
\hline 6 & $08 / 03 / 2021$ & 0,025 & 0,044 & $-0,002$ & 0,021 & 26 & $30 / 03 / 2021$ & 0,023 & 0,046 & $-0,004$ & 0,021 \\
\hline 7 & $09 / 03 / 2021$ & 0,022 & 0,042 & 0,000 & 0,021 & 27 & $31 / 03 / 2021$ & 0,023 & 0,041 & 0,002 & 0,021 \\
\hline 8 & $10 / 03 / 2021$ & 0,012 & 0,044 & $-0,002$ & 0,021 & 28 & $01 / 04 / 2021$ & 0,023 & 0,051 & $-0,008$ & 0,021 \\
\hline 9 & $11 / 03 / 2021$ & 0,025 & 0,045 & $-0,003$ & 0,021 & 29 & $02 / 04 / 2021$ & 0,025 & 0,045 & $-0,003$ & 0,021 \\
\hline 10 & $12 / 03 / 2021$ & 0,023 & 0,042 & 0,000 & 0,021 & 30 & $03 / 04 / 2021$ & 0,015 & 0,045 & $-0,003$ & 0,021 \\
\hline 11 & $13 / 03 / 2021$ & 0,022 & 0,044 & $-0,001$ & 0,021 & 31 & $04 / 04 / 2021$ & 0,030 & 0,047 & $-0,005$ & 0,021 \\
\hline 12 & $14 / 03 / 2021$ & 0,019 & 0,043 & $-0,001$ & 0,021 & 32 & $05 / 04 / 2021$ & 0,012 & 0,045 & $-0,003$ & 0,021 \\
\hline 13 & $15 / 03 / 2021$ & 0,026 & 0,041 & 0,001 & 0,021 & 33 & $06 / 04 / 2021$ & 0,025 & 0,045 & $-0,003$ & 0,021 \\
\hline 14 & $16 / 03 / 2021$ & 0,018 & 0,045 & $-0,003$ & 0,021 & 34 & $07 / 04 / 2021$ & 0,020 & 0,048 & $-0,006$ & 0,021 \\
\hline 15 & $17 / 03 / 2021$ & 0,023 & 0,048 & $-0,006$ & 0,021 & 35 & $08 / 04 / 2021$ & 0,012 & 0,048 & $-0,006$ & 0,021 \\
\hline 16 & $18 / 03 / 2021$ & 0,023 & 0,044 & $-0,002$ & 0,021 & 36 & $09 / 04 / 2021$ & 0,014 & 0,051 & $-0,008$ & 0,021 \\
\hline 17 & $19 / 03 / 2021$ & 0,020 & 0,048 & $-0,006$ & 0,021 & 37 & $10 / 04 / 2021$ & 0,023 & 0,046 & $-0,004$ & 0,021 \\
\hline 18 & $20 / 03 / 2021$ & 0,014 & 0,050 & $-0,008$ & 0,021 & 38 & $11 / 04 / 2021$ & 0,033 & 0,051 & $-0,009$ & 0,021 \\
\hline 19 & $21 / 03 / 2021$ & 0,026 & 0,044 & $-0,002$ & 0,021 & 39 & $12 / 04 / 2021$ & 0,013 & 0,043 & $-0,001$ & 0,021 \\
\hline 20 & $24 / 03 / 2021$ & 0,026 & 0,042 & 0,000 & 0,021 & 40 & $13 / 04 / 2021$ & 0,010 & 0,046 & $-0,003$ & 0,021 \\
\hline & & & & & & 41 & $14 / 04 / 2021$ & 0,024 & 0,045 & $-0,002$ & 0,021 \\
\hline
\end{tabular}

Berdasarkan hasil perhitungan di atas, semua data berada dalam spesifikasi artinya tidak ada lagi data yang perlu dibuang. Selanjutnya, kita buat grafiknya yang menunjukkan hasil perhitungan kita yang baru seperti sebelumnya yaitu sebagai berikut: 


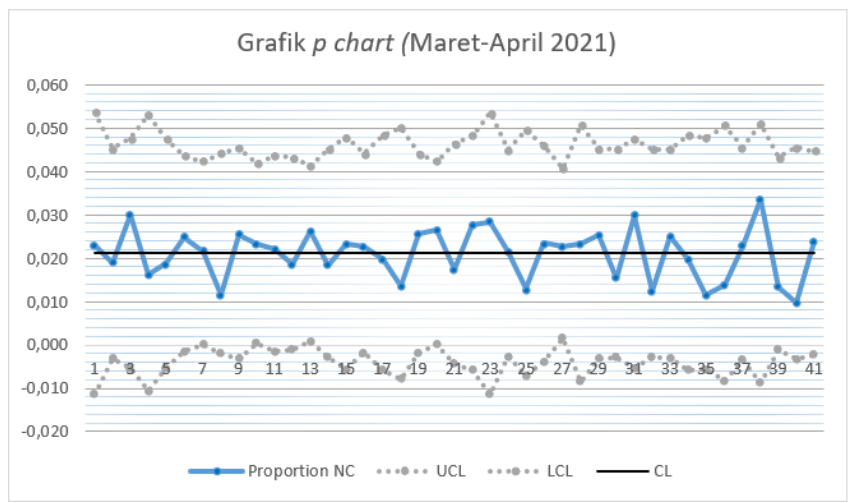

Gambar 8. Grafik p chart

Setelah mendapatkan bagan kendali tersebut, selanjutnya membuat bagan kendali tersebut menjadi standar, artinya batas atas dan batas bawah masing-masing memiliki proporsi yang sama yaitu $3 \sigma$. Berikut hasil perhitungan dari bagan kendali yang telah dibuat menjadi standar, dengan rumus yang sama.

$$
\begin{gathered}
C L=\bar{p}=\frac{265}{12560}=0,021 \text { dan } \bar{n}=\frac{12560}{41}=306,34 \\
U C L=\bar{p}+3 \sqrt{\frac{\bar{p}(1-\bar{p})}{\bar{n}}}=0,021+3 \sqrt{\frac{0,02(1-0,02)}{306,34}}=0,045 \\
L C L=\bar{p}-3 \sqrt{\frac{\bar{p}(1-\bar{p})}{\bar{n}}}=0,021-3 \sqrt{\frac{0,02(1-0,02)}{306,34}}=0
\end{gathered}
$$

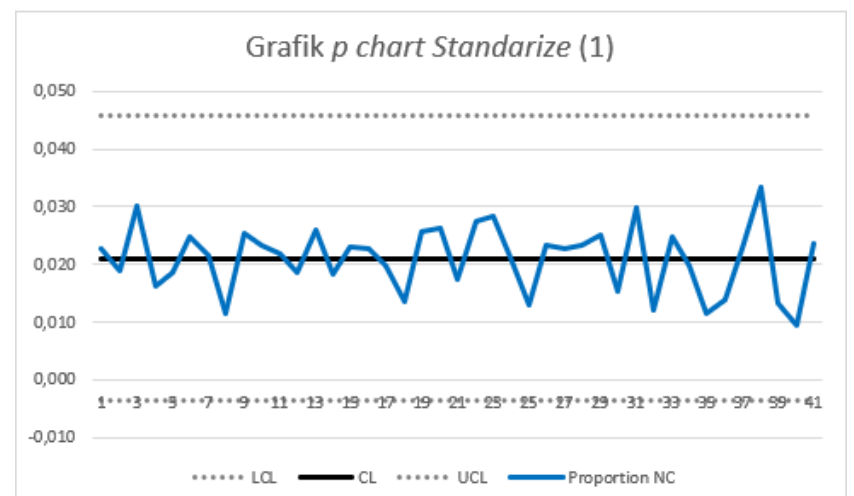

Gambar 9. Grafik $p$ chart standarize

\subsection{Uji Hipotesis}

Uji hipotesa ini bertujuan untuk mengetahui apakah bagan kendali kedua (setelah perbaikan) memiliki perubahan rata-rata proses menjadi lebih baik atau memang tidak ada perbedaan yang signifikan dari began kendali pertama (sebelum perbaikan). Dengan perhitungan sebagai berikut:

$>$ Uji hipotesis perubahan rata-rata proses

$$
\begin{aligned}
& \mathrm{H}_{0}: p_{1}=p_{2} \\
& \mathrm{H}_{1}: p_{1}>p_{2}
\end{aligned}
$$

$>$ Penentuan kriteria penerimaan (tingkat kepercayaan $n \& Z_{\alpha}$ )

$$
\begin{aligned}
& a=0,05 \\
& Z_{a}=1,645
\end{aligned}
$$

$>$ Perhitungan $\mathrm{p}$ dan $\mathrm{Z}_{0}$

$$
\begin{array}{ll}
p_{1}=0,120 & n_{1}=10157 \\
p_{2}=0,021 & n_{2}=12560
\end{array}
$$




$$
\begin{aligned}
p & =\frac{n 1 p 1+n 2 p 2}{n 1+n 2}=\frac{(10157 \times 0,120)+(12560 \times 0,021)}{(10157+12560)}=0,065264 \\
Z_{0} & =\frac{p 1-p 2}{p(1-p)\left(\frac{1}{n 1}+\frac{1}{n 2}\right)}=\frac{0,120-0,021}{0,065264(1-0,065264)\left(\frac{1}{10157}+\frac{1}{12560}\right)}=2,0578
\end{aligned}
$$

Karena $\mathrm{Z}_{\mathrm{o}}>\mathrm{Za}$ maka $\mathrm{H}_{0}$ ditolak, artinya terjadinya perbaikan terhadap proses dapat diverifikasi karena secara statistik. Dapat diperlihatkan bahwa perbaikan terjadi ditunjukkan dengan nilai $p_{2}$ yang lebih rendah dari $p_{1}$.

\subsection{Perbandingan sebelum dan setelah perbaikan}

Berdasarkan data produk cacat pada periode pertama dan periode kedua, terdapat perbandingan di antara kedua data tersebut. Gambar 10 menunjukkan perbandingan data produk cacat sebelum (warna biru) dan sesudah (warna merah) perbaikan.

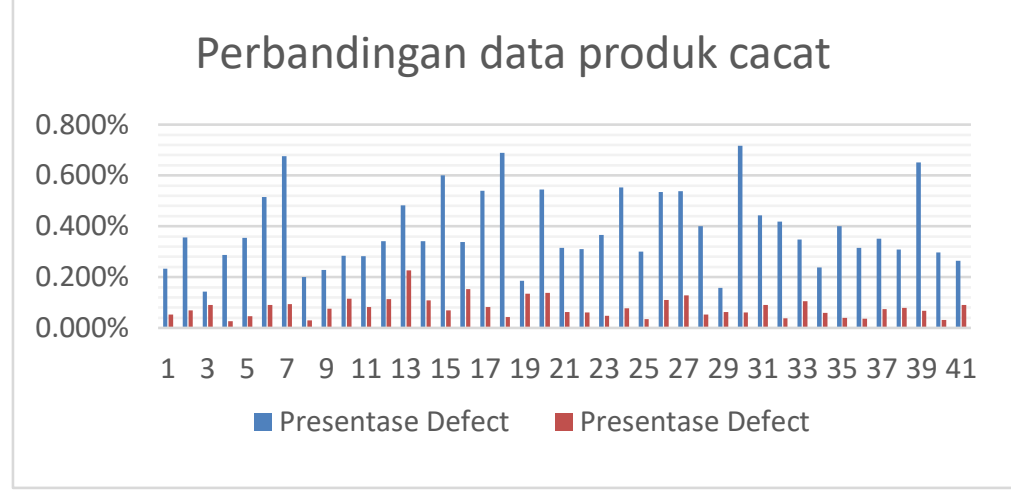

Gambar 10. Grafik perbandingan produk cacat

Berdasarkan Gambar 10 di atas, dapat dilihat perbandingan presentase jumlah produk cacat sebelum dan setelah perbaikan di mana terjadi penurunan yang cukup signifikan, jika dihitung dalam satu hari terjadi penurunan presentase jumlah produk cacat pada proses labelling sebesar 0,31\% dan total presentase jumlah produk cacat pada proses labelling sebelum dilakukan perbaikan yaitu sebesar $15,838 \%$ dan setelah dilakukan perbaikan mengalami penurunan 12,594\% menjadi 3,244\%. Untuk menjaga kesinambungan perbaikan maka perlu dilakukan pembuatan prosedur operasi standar juga. Agar dapat menurunkan kembali prosentasi cacat yang telah menurun menjadi 3,244\% maka perlu dilakukan analisis Pareto kembali untuk melihat jenis cacat apa lagi yang perlu mendapat prioritas untuk direduksi. Ini akan menjadi projek perbaikan berikutnya.

\section{Kesimpulan}

Dari bagian-bagian sebelumnya yang memaparkan identifikasi sampai kepada evaluasi masalah dapat ditarik beberapa kesimpulan, antara lain:

$\checkmark \quad$ Kecacatan yang terjadi pada saat proses labelling dapat diminimalisir dengan mengatasi beberapa faktor penyumbang produk cacat tersebut, antara lain adalah penyimpanan label pada Gudang material kurang baik, kurangnya pelatihan pada tenaga kerja, belum adanya standar atau parameter dari operasional run-in mesin, serta proses pemuaian dari botol WIP MF Cussons $900 \mathrm{ml}$.

$\checkmark$ Adapun beberapa tindakan (corrective action) yang tepat dilakukan untuk mengurangi jumlah produk cacat pada proses labelling yaitu alokasi tempat untuk penyimpanan label MF Cussons $900 \mathrm{ml}$ dengan pengatur kestabilan suhu berupa AC, melakukan pelatihan dan sosialisasi untuk operator mesin labelling terkait jenis cacat, pembuatan dan penetapan parameter untuk operasional mesin dan melakukan tambahan proses aging sebelum botol WIP MF Cussons $900 \mathrm{ml}$ akan dipakai/ diproses.

\section{Referensi}

1. Heizer, J., \& Render, B. (2006). Operations Management (Manajemen Operasi). Jakarta: Salemba Empat.

2. Kaban, R. (2014). Pengendalian Kualitas Kemasan Plastik Pouch Menggunakan Statistical Procces Control (SPC) di PT Incasi Raya Padang. Jurnal Optimasi Sistem Industri, 13(1), 518-547 
DOI: https://doi.org/10.33021/jie.v6i2.1581 JIE, Vol. 6, No.2, September 2021: 103-115

3. Lestari, P. B. (2021). Company. Retrieved March 20, 2021, from https://www.bumimulia.com/company/history

4. Montgomery, D. C. (2013). Introduction to statistical quality control (7th ed). Wiley.

5. Mirzaei, N., Niroomand, S., \& Zare, R. (2016). Application of Statistical Process Control in service industry: A case study of the restaurant sector. Journal of Modelling in Management. 11(3), 763-782.

6. Suyadi, P. (2007). Filosofi Baru Tentang Manajemen Mutu Terpadu Abad 21. Kiat Membangun Bisnis Kompetitif, Jakarta: Bumi Aksara. 